UDC 332.021.8:631.155.13(477)

JEL Classification: Q11, Q18

DOI: https://doi.org/10.32317/2221-1055.201904097

E.K. BUKIN, post-graduate student*

\title{
Partial-equilibrium analysis of the Ukrainian sugar policy
}

The purpose of the article is to analyse the effect of Ukrainian sugar production policy on market equilibrium and understand how enforcement instruments of the production quota $(A)$ affect sugar market and the industry.

Research methods. We based out work on the partial-equilibrium approach of sugar supply and demand along with the elements of the welfare analysis. Using this methodology, we can understand how sugar market reaches equilibrium price and how exactly policy enforcement instruments affect it.

Research results. We conclude that current sugar production quota in Ukraine is distributed on a non-competitive basis causing high domestic prices and largely negative effect on the sugar market and industry development. As efficient and competitive producers get access to low quota volumes, market setup provides little incentive to invest and improve competitiveness remaining sugar production at the level near sufficient for the domestic demand.

Elements of scientific novelty. The research contributes to the literature on the partial-equilibrium analysis of agricultural policy instruments such as production quota. Novelty lays in the fact that Ukrainian case of the flexible production quota has never been described before and we propose a mechanism of explaining market effects of such agricultural policy.

Practical significance. We suggest and justify alternative policies such as properly enforced production quota, tradable production quota and full liberalisation and discuss their implication for the market and industry. We demonstrate analytically that all three alternatives have a positive effect on the total welfare, lowering the price and increasing the production volumes. Tabl.: 1. Figs.: 5. Refs.: 26.

Keywords: partial-equilibrium analysis; sugar policy; Ukraine; production quota; welfare analysis; sugar import.

Bukin Eduard Kostiantynovych - post-graduate student of the department of economic cybernetics, National University of Life and Environmental Sciences of Ukraine (15, Heroiv Oborony st., Kyiv)

E-mail: edwardbukin@gmail.com

ORCID iD https://orcid.org/0000-0002-1003-1260

Scientific problem. Sugar is the second most important source of energy and accounts for $14.1 \%$ of the daily calorie intake of an average Ukrainian [1]. Specific climatic condition allows to grow sugar beet at the industrial scale and produce sugar out of sugar beets. Up to 192 refineries operated in 19 out of 25 regions of Ukraine between 19701990 yielding in 5 million tons of sugar per year. With the structural shifts after USSR's decay, sugar production volume declined to a 2013-2018 average of 1.5 million tons [2] and up to 40 operating refineries. From a major sugar exporter, sending up to 3.5 million tons of sugar per year, Ukraine become a net importer of sugar. Sugar industry become technologically outdated and inefficient, failing to meet international quality standards, demon-

\footnotetext{
* Scientific supervisor - A.V. Skrypnyk, doctor of economic sciences, professor.

(C) E.K. Bukin, 2019
}

strating low processing capacities and inferior energy use [3]. Open markets made it sensitive to economic fluctuations, vulnerable to the political agenda $[4,5]$ and investors rarely found this industry attractive [6].

Aiming at ensuring food security and improving competitiveness of the sugar industry, Ukrainian Government implemented sugar production quota policy and sugar import tariffs supported by restrictive quota and license in 1999 (starting from 2000 th marketing year). Initially, sugar policy was a simplified pre2000 EU sugar policy, where government gained an autocratic right to control the sector [7]. Slight change to the sugar trade policy was made in 2006 during negotiations of the WTO accession, where tariffs and restrictive quotas were modified to the Tariff-Rate Quota (TRQ). Currently, Ukrainian sugar policy consists of the following instruments:

- Sugar production quota (A), limiting production for domestic market; 
- Minimal prices for sugar beet and sugar produced under quota;

- State interventional buying of sugar;

- $2 \%$ TRW on raw sugar up to 260 thousand tone and $50 \%$ on above TRQ import,

- $50 \%$ tariff on refined sugar import;

In addition, Government implements a number of technical mechanisms restraining sugar industry. Among those are: (1) tolling restriction forbidding import of raw sugar for refining and immediate export; (2) licences on sugar trade and processing operation; (3) semi-official institutional structure of the sugar industry, chaired by the "Association of sugar producers 'UKRTSUKOR'” [3, 8, 9].

Analysis of recent researches and publications. At the time of the sugar policy adoption, concerns were voiced about potential of such a protective sugar policy measure. Von Cramon-Taubadel [10] argued that production quota system will not address competitiveness of Ukrainian sugar industry and increase price on staple foodstuff. Other authors' also casted doubts on the optimality of governmental resource allocation through quota [5]. Essential efficiency of the refining industry is a key to improving competitiveness. Currently, refining industry is characterised by short duration of the sugar processing period, low daily processing capacities, inefficient use of energy and low quality of the final product [3]. The only way to improve is in the technical change created by investments. Capital intensification of the sugar production and establishing of the long-term relationship with the beet supplier could drive positive changes in sugar production efficiency [11].

Two decades later, sugar policy yielded in costly sugar produced domestically on outdated equipment and uncompetitive refineries that barely satisfies domestic demand. Allocation of the sugar production quota and administration of the price support do not function properly. Productive year results into lower margins instead of expansion. Volatility and uncertainty of the domestic sugar prices, intrinsically linked to the quota on production, creates an opportunity for sugar substitutes to penetrate domestic market and increase is share $[12,13]$.

Given that, the purpose of the present paper is to reveal factors causing failure of current sugar policy and show how enforcement mechanism perverts political instruments. To present this, we structure our paper in the fol- lowing manner. After introduction, we briefly describe policy enforcement mechanisms in section 2 . In the section 3 , we analyse partialequilibrium effect of current policy and its alternatives. In section 4, we discuss the implication of the partial-equilibrium analyses and hypothesise main policy alternatives. Section 5 is a conclusive one.

Research results. The key to understanding reasons of failure of the Ukrainian sugar policy is in the enforcement mechanisms used for implementing simple policy instruments. Let us have a detailed look at the most important policy aspects.

Trade policy, while being a theoretically acceptable measure to protect domestic market, yields with rather ambiguous consequences. Ever since $1990^{\text {th }}$ domestic prices remained significantly higher than the World prices of the same quality refined sugar ("REF World Price" line on the Figure 1), however, because the import parity price was lower than domestic price, import kept on occurring (Figure 1). TRQ introduction in 2006 significantly reduced import to below TRQ levels mainly because it leveraged import parity prices for the raw sugar, making it too expensive to import. Domestic prices, however, remained in between raw sugar import parity and the refined sugar world prices, leading to the artificial autarky market regime. In the autarchy market, Ukrainian refineries operate in the status quo: free from competition with the world market. Such market conditions neither causing refineries to quit, nor stimulates them to improve competitiveness because they are left only to compete among each other. As a result, consumers are paying for high domestic prices of sugar about $0.5 \%$ of the Ukrainian GDP and production remains domestic-market oriented failing to meet quality standards sufficient for export $[11,13,14]$.

Besides restricting trade for domestic consumption, government forbids any tolling operations with sugar, which occur when imports of raw sugar is not intended for the domestic market but to be only directly exported. During the tolling operations, sugar refineries are not paying import tariffs, because the final product is not intended for the domestic market. Therefore, tolling operations allow refineries run longer, maintaining lower marginal costs, and consequently improve their competitiveness [8]. 


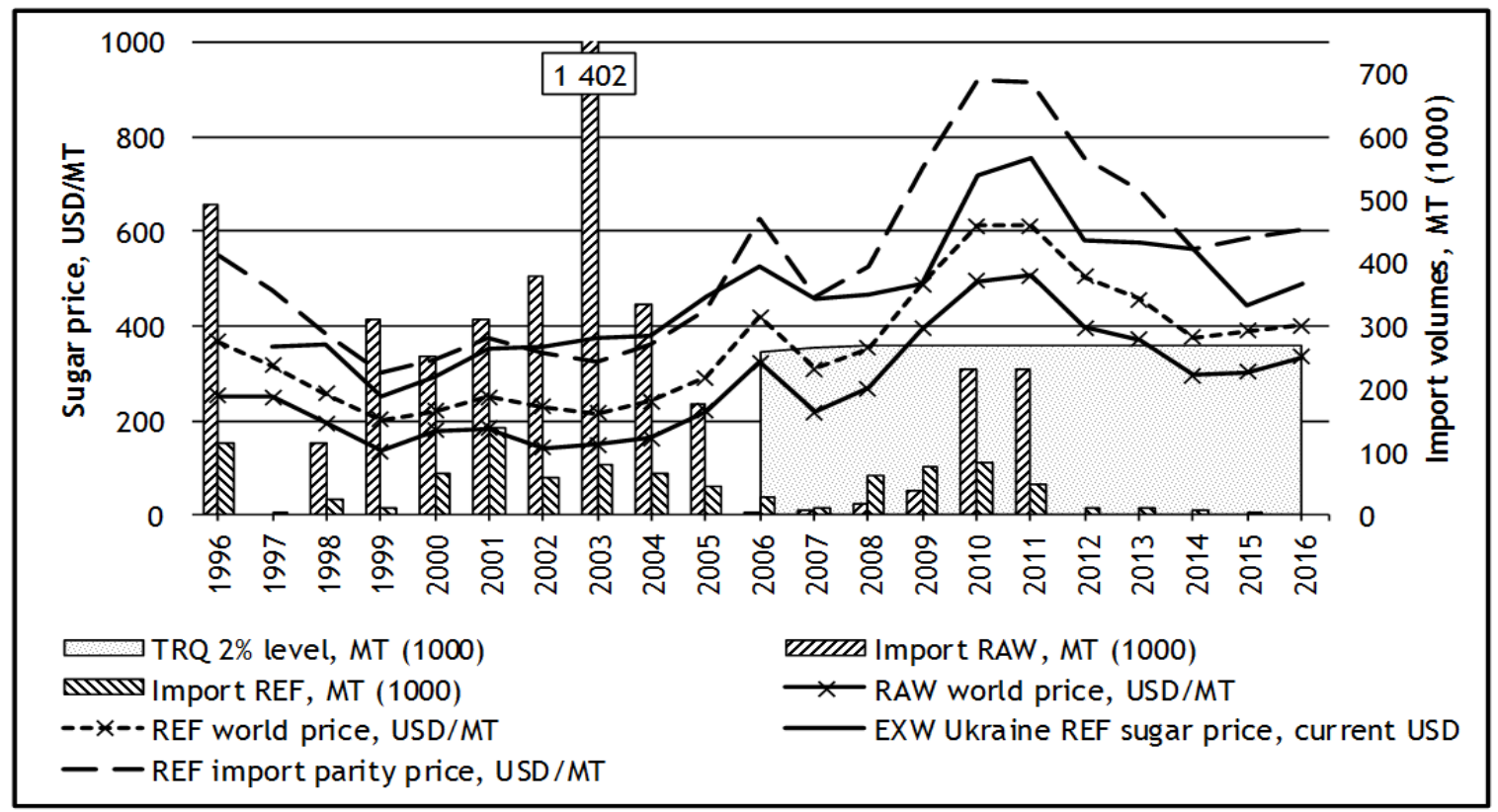

Figure 1. Sugar import volumes and prices

Source: Own calculations based on data from [2].

State interventional buying mechanism aims at ensuring food security and is not designed to assist sugar industry. It affects, however, domestic prices. Unfortunately, this instrument is intransparent. Information on prices, volumes and interventions in sugar market in not disclosed. (Figure 2) illustrates the (dejure) volumes of the interventional buying in different marketing years and prices existed in the same year. Although, it is impossible to distinguish to what extent interventional buying affect the market, secrecy surrounding this policy instrument suggest about possible hidden agenda in this policy instrument.
Minimal prices are implemented, together with the sugar production quota and are rather declarative. The law stipulates that refineries must not sell sugar at the price below minimal as well as refineries must not pay for beets prices lower than the minimal. In addition, there are penalties for violating this rule. However, Government has never applied any penalties to the refineries, since the implementation of the policy. Given that up to $85 \%$ of beet is purchased in an exchange for refined sugar instead of cash [15], it is likely that the minimal prices instrument is not enforced at all and has only a declarative nature.

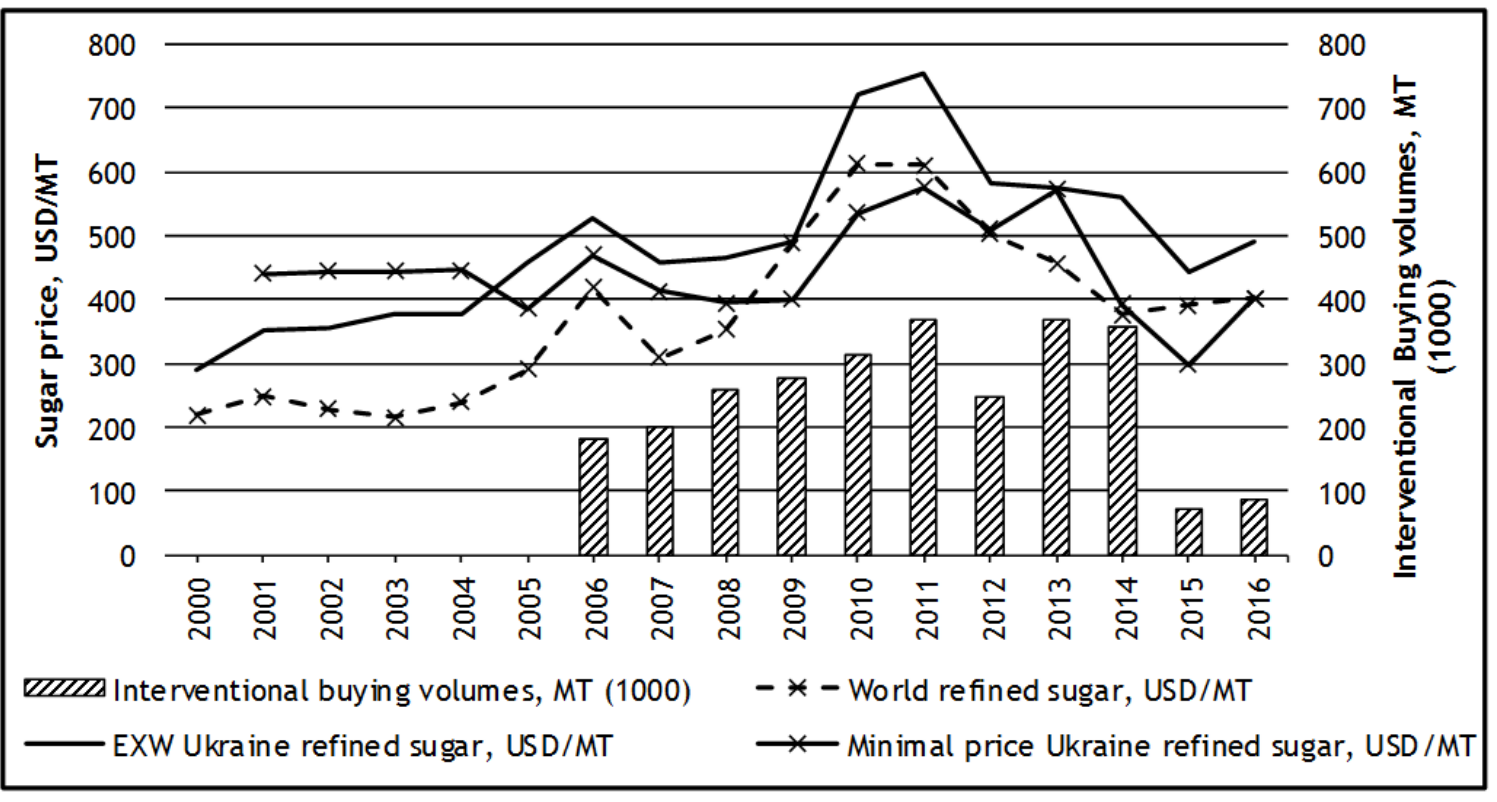

Figure 2. Interventional buying of sugar and domestic prices

Source: Own calculations based on data from [2]. 
Production quota $(A)$ is a refinery specific untradeable quota, which limits beet sugar production intended for the domestic market, without restricting sugar production from imported raw sugar [7]. Annually, policymakers decide on the volume of the quota $(A)$ distribution between refineries, selecting them on 'a competitive basis' [16].

Competitive basis of quota allocation is a key here. Due to the lack of transparency of the quota distribution procedure, researches hypothesise that criterion for quota distribution between refineries could be in contracted beets areas per region and the regional tendency towards vertical integration [11, 14].

Table 1 shows the dynamics of sugar quota (A) distribution over time in Ukraine. In the table, "Initial quota" stands for the amount of sugar under quota (A) distributed among refineries at the beginning of the marketing year. "Final quota" indicates amount of quota (A) designated in the end of the marketing year. From the "Number of revisions" we can see how many times per year volumes of quota (A) were revised and their distribution was changed. In 2000-2016, Government revised production quota at least once a year, changing it in the middle or in the end of the production season and simply making it flexible.

As more comprehensive studies suggests [15], annual revision of quota is made not only for adjusting country level of quota $(A)$, but also for re-distributing quota $(A)$ between refineries to the actual levels of sugar production. Ukrainian Government adjusts quota (A) volumes in bad and good production seasons always "fitting" quota level to the actual sugar production levels at refineries. Therefore, because every refinery produce exactly that amount of sugar that has been specific and adjusted in quota $(A)$, penalties for under or over-production are never applied to the refineries.

It is clear that in such enforcement, production quota become a solely declarative instrument. It is in fact "flexible" and only granting a right to produce sugar for refineries. Consequently, instead of stimulation and restriction, it become a political instrument of access to the sugar market [15].

Table. Enforcement of the sugar production quota "A"

\begin{tabular}{|l|c|c|c|c|c|c|c|c|}
\hline & $\begin{array}{l}\text { Average } \\
\mathbf{2 0 0 1 / 1 0}\end{array}$ & $\mathbf{2 0 1 1}$ & $\mathbf{2 0 1 2}$ & $\mathbf{2 0 1 3}$ & $\mathbf{2 0 1 4}$ & $\mathbf{2 0 1 5}$ & $\mathbf{2 0 1 6}$ & $\begin{array}{c}\text { Average } \\
\mathbf{2 0 0 1 / 1 5}\end{array}$ \\
\hline Number of revisions & 2.3 & 2 & 2 & 2 & 2 & 2 & 2 & 2.2 \\
\hline Initial quota & 1797.4 & 1892 & 1860 & 1833 & 1733 & 1811 & 1720 & 1801 \\
\hline Final quota & 1623.1 & 1546 & 1860 & 1833 & 1528 & 1811 & 1682.85 & 1656 \\
\hline Difference: Final-Initial & -174.3 & -346 & 0 & 0 & -205 & 0 & -37.15 & -146 \\
\hline Beet production & 1722 & 1546 & 2331 & 2226 & 1212 & 1459 & 2008 & 1752 \\
\hline
\end{tabular}

Source: Own calculations based on official legislation [15, 17].

On the quota implementation side, mechanisms and procedures used for quota enforcement are purely administrative, what creates grounds for corruption and rent seeking behaviour [18]. Overall, enforcement of sugar production quota at the refineries' level rises debates and questions quota existence, as such [13]. Government does not utilise capacities of production quota $(A)$, as a mechanism purposed to stimulate competition between producers, therefore, quota "do nothing to change the fundamental lack of competitiveness of the Ukrainian sugar industry" [10].

As government neglects competitiveness in production quota distribution, it eliminates competition from the domestic market, and creates a group of the rent-driven beneficiaries, who constantly receives quota permits [19]. Multiplying the rent of the beneficiaries who have access to quota, minimal prices make the sugar policy opaque and costly [20]. Given that quota create rents for those who successfully lobby for it, political economy of sugar quota in Ukraine should be considered and treated carefully.

Partial-equilibrium effect of the production quota

Let us analyse how uncompetitive quota distribution affects equilibrium prices on the market using partial-equilibrium approach and an example of three firms. Each firm has individual supply curve $S_{1}, S_{2}$, and $S_{3}$, which correspond to their competitiveness level $(\mathbf{C}(\mathrm{S})$ ) (Figure 3, left side). Firm $S_{1}$ is the most competitive as it is capable of supplying more sugar at the lower price, firm $S_{2}$ is in the middle and firm $S_{3}$ is the least competitive $\left(\mathbf{C}\left(\mathbf{S}_{1}\right)>\mathbf{C}\left(\mathbf{S}_{2}\right)>\mathbf{C}\left(\mathbf{S}_{3}\right)\right)$. Together, these three firms aim at satisfying domestic demand $D$.

In the perfect competition and open market, each firm start to produce when price 
reaches individual marginal production costs. Therefore, each additional firm contributes to the sugar volume already supplied to the market. Figure 3 (right side), illustrate that only firms with the supply curves $\boldsymbol{S}_{1}$ and $\boldsymbol{S}_{2}$ will be

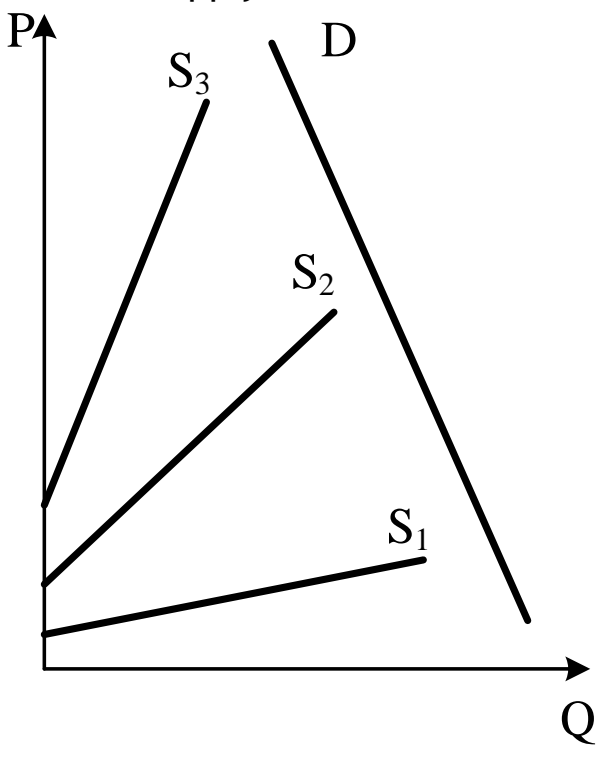

supplying $\mathbf{Q}_{1}$, and $\mathbf{Q}_{2}$ volumes of sugar to the market respectively at the equilibrium price $\mathbf{P d}_{3}$ and $\mathbf{Q}_{1}+\mathbf{Q}_{2}$. Firm with the supply curve $\boldsymbol{S}_{3}$ will remain out of market and won't produce at all.

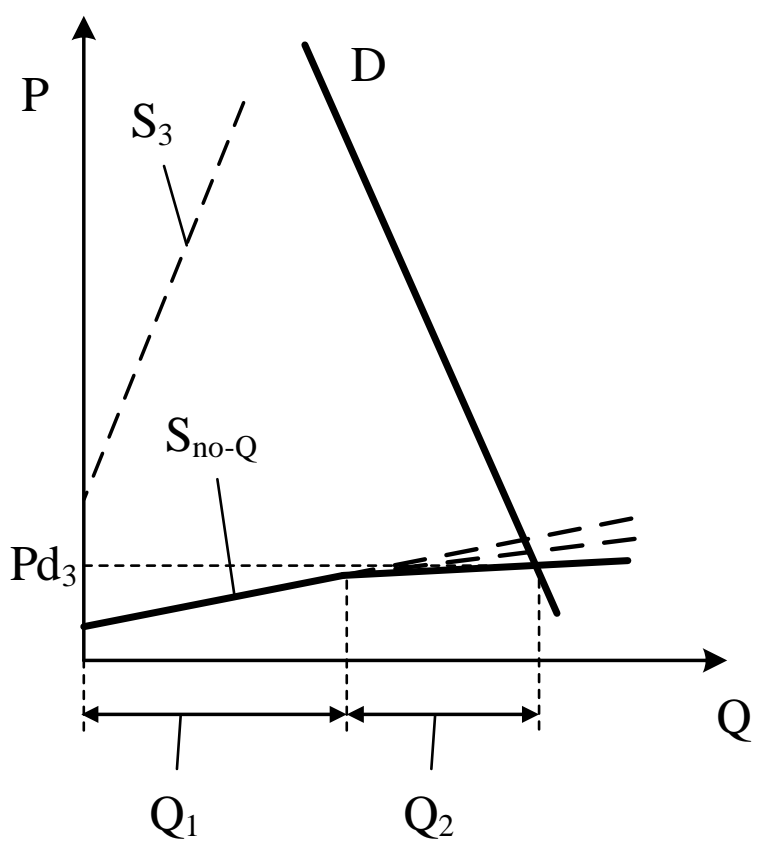

Figure 3. Effect of the properly enforces production quota on the market of three firms

Source: Own development.

Imagine an alternative situation with the same tree producers $\left(\mathbf{S}_{1}, \mathbf{S}_{2}\right.$, and $\left.\mathbf{S}_{3}\right)$ acting on the market with the properly enforced production quota (Quota) - Figure 4 (A). Government aims at maintaining prices at the reasonable level in order to maintain production of many producers, build sugar refining capacity and stimulate competitiveness improvement on the market. It distributes production quota on a competitive basis; therefore, Quo$\mathrm{ta}=\mathrm{Sq}_{1}+\mathrm{Sq}_{2}+\mathrm{Sq}_{3}$ and $\mathrm{Sq}_{1}>\mathrm{Sq}_{2}>\mathrm{Sq}_{3}$, where $\mathrm{Sq}_{1}$, $\mathrm{Sq}_{2}$, and $\mathrm{Sq}_{3}$ are the volumes of the quota allocated to each firm $S_{1}, S_{2}$, and $S_{3}$ respectively. Here, quota is also allocated to each producer including least competitive firm $\mathrm{S}_{3}$, however, quota volume is proportional to the level of competitiveness.

On the Figure 4 (left side), three sugar producers supply sugar accordingly to their quotas, making the aggregated supply function $S_{\text {enf-Q }}$ (bold line). The aggregated supply function $S_{\text {no-Q }}$ achieves an equilibrium with the demand function $\mathbf{D}$, when the price is $\mathbf{P d}_{1}$. Proper enforcement of the production quota increases domestic prices compare to the open market and yields into lover level of sugar production.
"Flexible" sugar production quota has a radically different impact on the market equilibrium, Figure 4 (right side). When quota is distributed on a non-competitive basis, we have more quota allocated to the less competitive firms, thus Quota $=S^{`} q_{1}+S^{`} q_{2}+S^{`} q_{3}+S^{\prime} q_{4}$ when $S^{\prime} q_{1}<S^{\prime} q_{2}<S^{\prime} q_{3}+S^{\prime} q_{4}, \quad\left(S^{\prime} q_{1}, S^{\prime} q_{2}\right.$ and $S^{\wedge} q_{3}+S^{`} q_{4}$ are quotas for firms $S_{1}, S_{2}$; and $S_{3}$ respectively). Such uncompetitive quota allocation, has several consequences:

- the firm $S_{3}$ utilize only $S^{\prime} q_{3}$ amount of the allocated quota, decreasing the potential total production of sugar in the country by $\mathrm{S}^{`} \mathrm{q}_{4}$.

- the most competitive firm $S_{1}$ receives the lowest amount of quota $S^{\prime} \mathbf{q}_{1}$ or amount of quota disproportional to its competitiveness level; although, this firm can produce more for export or in account of the production quota for the next marketing year.

- firm $S_{2}$ has high fixed costs, it only starts producing sugar after the firm $\boldsymbol{S}_{1}$ utilizes all amount of quota $S^{\wedge} q_{1}$ and the prices increased with the level $\Delta \mathrm{P}$ compare to the prices gained with the sugar production by the first firm. That slightly increases domestic prices without producing additional sugar. 

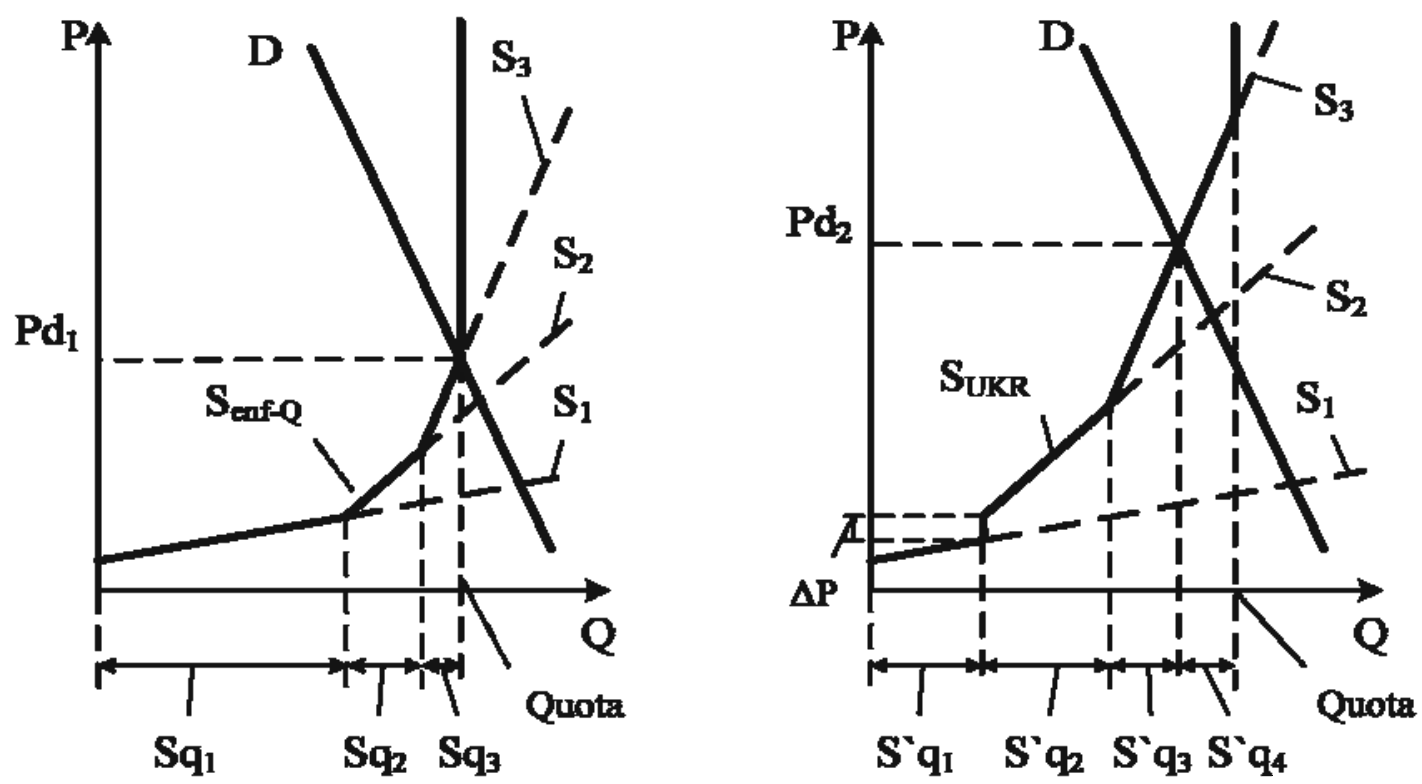

Figure 4. Effect of the production quota enforced in Ukraine on the market of three firms

Source: Left figure is adopted from [21], right figure is own development.

Eventually, market achieves equilibrium price $\mathbf{P d}_{2}$, in the point, where the aggregated supply curve Sukr (bold line) meets the demand $\mathrm{D}$. The equilibrium price on the Ukrainian market $\mathbf{P d}_{2}$ becomes significantly higher, than the equilibrium price $\mathbf{P d}_{1}$ on the market with the properly enforced quota.

Figure 4 (B) formalises situation observed on the Ukrainian market, where production quota "...forces inefficient refineries to produce sugar; although, it does not make sense either financially (from the factory's point of view) or economically (from the national economy's point of view)" [11]. This analysis also shows that uncompetitively allocated production quota could be an influencing mechanism affecting the domestic price. That is in particularly interesting finding that contributes to the existing so-called "classic factors" widely accepted in Ukrainian literature as influencing domestic prices of Sugar [22, 24].

It is clear that properly enforced quota may create favourable market conditions compare to the flexible quota, decreasing prices to the level $\mathbf{P d}_{2}$ from the level $\mathbf{P d}_{1}$, but remaining them still high compare to the open market and high enough to preserve production for all producers and maintain competition on the market. This may still not resolve the problem of the producer's competitiveness and efficiency due unattractive nature of the production quota measure [23]. In order to create actual competition on the sugar market, the quota must be fully abolished.

\section{Discussion}

Comparing partial-equilibrium effect of three scenarios, namely market with "flexible" quota - SuKR, with enforced quota - S Senf-Q and with no quota - $S_{\text {no-Q }}$, suggests several findings Figure 5 . Abolition of the quota leads to the significant production and consumption expansion $\left(\mathbf{Q s}_{3}\right)$ at the lower equilibrium price. Although, producers loose surplus due to price reduction to $\mathrm{Pd}_{3}$, compare to the properly enforced quota and "flexible quota", quota abolition may create competition on the domestic market setting aside some inefficient producers. In theory, establishing tradable quota could lead to similar consequences as full quota liberalization, with the slightly higher domestic prices in between $\mathbf{P d}_{1}$ and $\mathbf{P d}_{3}$. This may be unfeasible in the Ukrainian realities as production is concentrated in the hands of the vertically integrated producers and there is no sufficient institutions to manage such policy option.

Finally, enforcement of the flexible production quota is harmful to the industry as it prevents competition and artificially increases prices. As producers have no incentive to improve, the industry does not undergo restructuring process and remains in status quo. Despite having high producers' surplus, overall welfare effect is much lower than that achieved with free market or proper production quota. 


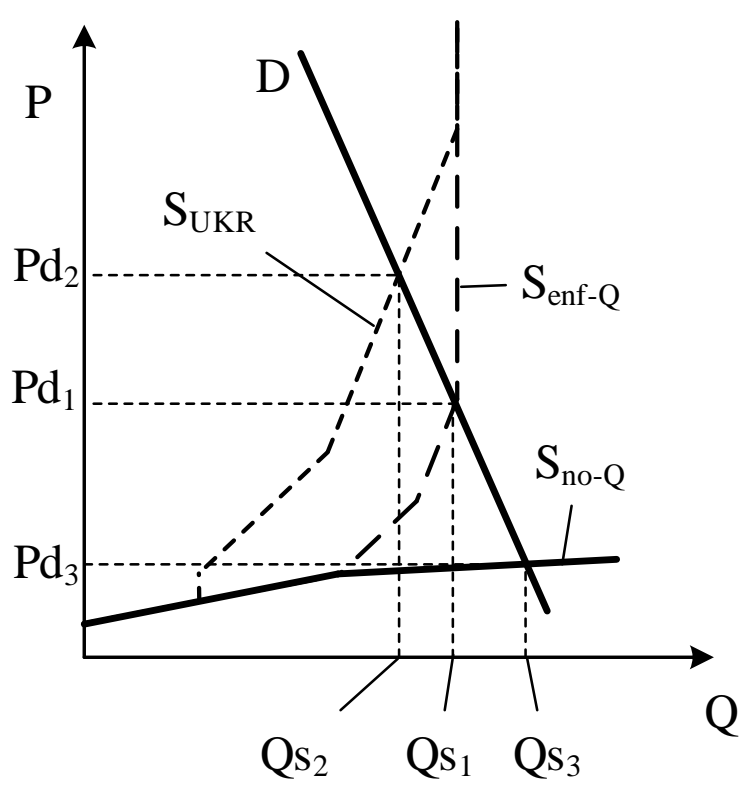

Figure 5. The effect of the quota abolition on the Ukrainian sugar market

Source: Own development.

Policymakers may argue that production quota liberalisation may relax protection of sugar industry from the global market. In fact, it will only force domestic competition and not with the world. The world market will remain separated from the domestic with the import tariffs and TRQ. Another argument against market liberalisation is in low competitiveness of beet against other cash crops. However, this is not the case of Ukraine, where there are regions favourable for beet production. In addition, achieving high yields creates competitive margins of sugar beet compare to other crops [10,11, 25].

It is important to be aware of possible negative externalities of the quota abolition, which may occur due quitting of some agents from the market. Sugar quota abolition may lead to the shrinking of sugar industry with the loss of job for 23 to 60 thousand employees. Although, such judgments are based on a very rough reasoning, the social aspect of the quota abolition need to be assessed carefully $[15,26]$.

In order to cope with the potential social externalities, it is important to understand whether it would be more beneficial to redirect public financial allocations from the sugar industry (e.g. from annual interventional buying) to other job-creating sectors (e.g. infrastructure) in the sugar producing regions. Such reallocation of resources, besides creating jobs, may also decrease sugar production costs in the concerned regions, due to the infrastructural improvements [20].
Conclusions. Current sugar production policy in Ukraine is enforced in a perverted way creating unequal opportunity to the producers. In particular, distribution of the production quota occurs on a non-competitive basis acting as market access instrument rather than the distribution mechanism. Absence of competition between producers on the domestic market prevent restructuring of the industry and any improvement in its competitiveness.

Partial-equilibrium analysis shows, that "flexible" production quota negatively affects overall welfare of the industry generating substantial producers' surplus at the cost of the high prices paid by consumers. Besides, additional indirect mechanisms that restrict sugar industry (tolling restrictions or current institutional structures) have own negative effect, which should be carefully analysed and treated respectively. At the same time, alternative policy choices such as full market liberalisation or proper production quota enforcement may have a significant positive effect on the industry.

Nevertheless, many unobservable uncertainties remain such as social externalities of sugar industry restructuring, unstable political agenda and short planning horizon. Limited political willingness to change current order and improve largely disinterested private investors, delaying technological and competitiveness improvements. This leaves us with the broad field of policy aspects pending on deeper analysis and investigation. Among 
those are data-driven quantitative simulation of the possible policy scenarios, deeper investigation of the various policy aspects and mo-

\section{References}

1. Food balance sheets. Rome, Italy : Food and Agriculture Organization of the United Nations (FAOSTAT), 2015. URL : http://www.fao.org/faostat/en/\#data/FBS.

2. Статистичний щорічник України за 2016 рік. Київ : Державна служба статистики України, 2018. URL : http://www.ukrstat.gov.ua/.

3. Матеріали науково-технічної конференції цукровиків України «Бурякоцукрова галузь в умовах національного та світового ринків»-Київ : Національна Ассоціяція Цукровиків України «УКРЦУКОР» 2015. 267 с.

4. Balmaceda M. M. Explaining the management of energy dependency in Ukraine: possibilities and limits of a domesticcentered perspective. Mannheimer Zentrum für Europäische Sozialforschung, Untersuchungen des FKKS. 2004. No. 30. P. 38.

5. Benecke C., Cramon-Taubadel S. von. The present and future profitability of sugar production in Ukraine. Policies and Agricultural Development in Ukraine / S. Zorya, S. von CramonTaubadel, L. Striewe (eds.). 2001. P. 214-240.

6. Zorya S., Nivyevskiy $O$. Reforming of sugar market organization in the EU: lesson for Ukraine. German Advisory Group and Institute for Economic Research and Policy Consulting in Ukraine. 2005. Vol. U, No. 5. P. 13.

7. Про державне регулювання виробництва та реалізації цукру : Закон України від 17.06.1999 № 758-XIV зі змінами від 16.10.2012 № 5462-VI. URL : https://zakon.rada.gov.ua/laws/ show/ru/5462-17.

8. Raw sugar toll refining - a sensible policy? / 0 . Nivyevskiy, A. Kuznetsova, S. Kandul, H. Strubenhoff. Institute for Economic Research and Policy Consulting. 2005. Vol. AgPP, No. 33. P. 23

9. Nivyevskiy, O., Strubenhoff, H. Restructuring of the Sugar Sector in Ukraine, Working Paper, IER. 2006. URL : https://www.researchgate.net/publication/282119501_Restruc turing_of_the_Sugar_Sector_in_Ukraine.

10. Cramon-Taubadel S. von. The market for sugar in Ukraine: past, present and future. Ukraine at the Crossroads: Economic Reforms in International Perspective / A. Siedenberg, L. Hoffman (editors). Heidelberg: Physica-Verlag HD, 1999. P. 117-130.

11. Strubenhoff H., Movchan V., Burakovsky $I$. Restructuring of the sugar sector in Ukraine. Agriculture, Bioenergy and Food Policy in Ukraine Analyses, Conclusions and Recommendations / H. Strubenhoff, O. Nivyevskiy. Kiev : Institute for Economic Research and Policy Consultating, 2009. P. 186-231.

12. The agri-food sector in Ukraine: current situation and market outlook until 2025: extension of the agmemod model towards Ukraine / M. Van Leeuwen, P. Salamon, T. Fellmann [et al.]. 2012. URL : https://www.researchgate.net/ publication/266912255_The_agri-

food_sector_in_Ukraine_Current_situation_and_market_outlook until 2025 .

13. Yarmak A., Prihodko D. Ukraine: sugare sector review report. No. 11. Rome : Food and Agriculture Organization, 2013. URL : http://www.fao.org/3/i3472e/i3472e.pdf.

14. Striewe $L$. Who gains and loses-import tariffs and tariff rate quotas for sugar and grain in Ukraine. Policies and Agricultural Development in Ukraine / S. Zorya, S. von Cramon-Taubadel, L. Striewe. Aachen : Shaker Verlag, 2001. P. 134-156.

15. Bukin E. Improving competitiveness of the Ukrainian sugar industry: economic instability and policy implications. Humboldt University of Berlin, 2015.

16. Cabinet of Ministry of Ukraine "About some issues of sugar production and supply regulation in Ukraine", order of the $\mathrm{cmu}$ no 868 from 02.06.2000 / Cabinet of Ministry of Ukraine. - Cabinet of Ministry of Ukraine, 2000. - 868 p. dalities as well as numeric evaluation of the welfare gains and losses caused by the political alternatives.

\section{References}

1. Food balance sheets (2015). Rome: Food and Agriculture Organization of the United Nations (FAOSTAT). Retrieved from: http://www.fao.org/faostat/en/\#data/FBS [In English].

2. Statystychnyi shchorichnyk Ukrainy za 2016 rik [Statistical yearbook of Ukraine for 2016]. (2018). Kyiv: Derzhavna sluzhba statystyky Ukrainy. Retrieved from: http://www.ukrstat.gov.ua [In Ukrainian].

3. Natsionalna asotsiatsiia tsukrovyrobnykiv Ukrainy [National sugar producers association of Ukraine]. (2015). Kyiv: Materialy naukovo-tekhnichnoi konferentsii tsukrovykiv Ukrainy [In Ukrainian].

4. Balmaceda, M.M. (2004). Explaining the management of energy dependency in Ukraine: possibilities and limits of a domestic-centred perspective. Mannheimer Zentrum für Europäische Sozialforschung, Untersuchungen des FKKS, 30, p. 38 [In English].

5. Benecke, C. \& Cramon-Taubadel, S.von (2001). The present and future profitability of sugar production in Ukraine. Policies and Agricultural Development in Ukraine. S. Zorya, S. von Cramon-Taubadel, \& L. Striewe (Eds.). (pp. 214-240) [In English].

6. Zorya, S. \& Nivyevskiy, O. (2005). Reforming of sugar market organization in the EU: lesson for Ukraine. German Advisory Group and Institute for Economic Research and Policy Consulting in Ukraine, Vol. U, No. 5, p. 13 [In English].

7. Pro derzhavne rehuliuvannia vyrobnytstva ta realizatsii tsukru : Zakon Ukrainy vid 17.06.1999 № 758-KhIV zi zminamy vid 16.10 .2012 № 5462-VI [On state regulation of sugar production and sale: Law of Ukraine dated 17.07.1999, No. 758-XIV, as amended on 16.10.2012, No. 5462-VI]. Retrieved from: https://zakon.rada.gov.ua/laws/show/ru/ 5462-17 [In Ukrainian].

8. Nivyevskiy, O., Kuznetsova, A., Kandul, S., \& Strubenhoff, H. (2005). Raw sugar toll refining - a sensible policy? Institute for Economic Research and Policy Consulting, Vol. AgPP, No. 33, p. 23 [In English].

9. Nivyevskiy, O., Strubenhoff, H. (2006). Restructuring of the Sugar Sector in Ukraine, Working Paper, IER. Retrieved from: https://www.researchgate.net/publication/282119501_ Restructuring_of_the_Sugar_Sector_in_Ukraine [In Ukrainian].

10. Cramon-Taubadel, S.von. (1999). The market for sugar in Ukraine: past, present and future. Ukraine at the Crossroads: Economic Reforms in International Perspective. A. Siedenberg \& L. Hoffman (Eds.). (pp. 117-130). Heidelberg: Physica-Verlag HD [In English].

11. Strubenhoff, H., Movchan, V., \& Burakovsky, I. (2009). Restructuring of the sugar sector in Ukraine. Agriculture, Bioenergy and Food Policy in Ukraine Analyses, Conclusions and Recommendations. (pp. 186-231). Kyiv: Institute for Economic Research and Policy Consulting [In English].

12. Leeuwen, M.van, Salamon, P., Fellmann, T., et al. (2012). The agri-food sector in Ukraine: current situation and market outlook until 2025: extension of the agmemod model towards Ukraine. Retrieved from: https://www.researchgate.net/ publication/266912255_The_agri-food_sector_in_Ukraine_Current situation_and_market_outlook_until_2025 [In English].

13. Yarmak, A. \& Prihodko, D. (2013). Ukraine: sugar sector review report. No. 11. Rome: Food and Agriculture Organization. Retrieved from: http://www.fao.org/3/i3472e/ i3472e.pdf [In English].

14. Striewe, L. (2001). Who gains and loses-import tariffs and tariff rate quotas for sugar and grain in Ukraine. Policies and Agricultural Development in Ukraine. (pp. 134-156). Aachen: Shaker Verlag [In English].

15. Bukin, E. (2015). Improving competitiveness of the Ukrainian sugar industry: economic instability and policy implications. Humboldt University of Berlin [In English]. 
17. Про розподіл між суб'єктами господарювання обсягів виробництва та поставки цукру квоти "А" на внутрішній ринок у період з 01 вересня 2017 року до 01 вересня 2018 року : Наказ Міністерства аграрної політики та продовольства України від 14.03.2017 № 130. URL : http://minagro.gov.ua/ organic_ministry?nid=23665.

18. Achieving Ukraine's agricultural potential stimulating agricultural growth and improving rural life. The World Bank, OECD. Paris and Washington, DC : The World Bank and OECD, 2004.

19. Kuhn A., Demyanenko S. Agricultural policy versus rural policy: core tasks and joint responsibility. Ukrainian Agriculture Crisis and Recovery / S. von Cramon-Taubadel, S. Demyanenko, A. Kuhn. Aachen : Shaker Verlag, 2004. P. 70-77.

20. Kuhn A., Nivyevskiy O. An ex-ante analysis of a minimum price system in Ukraine. IER Working Paper No. 31, Kiev, March 2005.

21. Nolte S., Buysse J., Van Huylenbroeck G. Abolition of the eu sugar quotas: what's at stake? International Sugar Journal. 2012. Vol. 114, No. 1359. P. 146-155.

22. Пархоменко Л. М. Виробництво цукру в Україні: стан, проблеми та шляхи їх вирішення. Економіка та управління АПК. 2012. No. 8. Р. 74-78.

23. Mahler $P$. Efficiency losses as a result of insufficient structural adjustments due to the ec sugar regime: the case of Germany. European Review of Agricultural Economics. 1994. Vol. 21, No. 2. P. 199-218.

24. Стасіневич C. A. Механізм державного цінового регулювання в цукробуряковому комплексі України. Бізнесінформ. 2013. №. 5. Р. 172-177.

25. Скрипник А. В., Жемойда О. В., Букін Е. К. Аналіз ефективності виробництва пшениці за методом Data Envelopment Analysis (DEA). Економіка АПК. 2017. № 1. С. 15-24.

26. Sustainable development facets: farmland market demand estimation / A. V. Skrypnyk, V. A. Tkachuk, V. M. Andruschenko, E. Bukin. Journal of Security and Sustainability Issues. 2018. Vol. 7. No. 3. URL : https://jssidoi.org/jssi/ papers/papers/journal/27.
16. On some issues of sugar production and supply regulation in Ukraine: Order of the Cabinet of Ministers of Ukraine dated 02.06.2000, No. 868. Cabinet of Ministers of Ukraine [In English].

17. Pro rozpodil mizh subiektamy hospodariuvannia obsiahiv vyrobnytstva ta postavky tsukru kvoty "A" na vnutrishnii rynok u period z 01 veresnia 2017 roku do 01 veresnia 2018 roku : Nakaz Ministerstva ahrarnoi polityky ta prodovolstva Ukrainy vid 14.03.2017 № 130 [On division between economic entities of a volume of production and delivery of sugar of the quota " $A$ " to the domestic market in the period between 1 September 2017 and 1 September 2018: Order of the Ministry of Agrarian Policy and Food of Ukraine dated 14.03.2017, No. 130]. Retrieved from: http: / /minagro.gov.ua/organic_ministry?nid=23665 [In Ukrainian].

18. Achieving Ukraine's agricultural potential stimulating agricultural growth and improving rural life. (2004). The World Bank, OECD. Paris and Washington: The World Bank and OECD [In English].

19. Kuhn, A. \& Demyanenko, S. (2004). Agricultural policy versus rural policy: core tasks and joint responsibility. Ukrainian Agriculture - Crisis and Recovery. (pp. 70-77). Aachen: Shaker Verlag [In English].

20. Kuhn, A. \& Nivyevskiy, O. (2005). An ex-ante analysis of a minimum price system in Ukraine. IER Working Paper, 31 [In English].

21. Nolte, S., Buysse, J., \& Huylenbroeck, G.van (2012). Abolition of the EU sugar quotas: what's at stake? International Sugar Journal, Vol. 114, No. 1359, pp. 146-155 [In English].

22. Parkhomenko, L.M. (2012). Vyrobnytstvo tsukru v Ukraini: stan, problemy ta shliakhy yikh vyrishennia [Production of sugar in Ukraine: state, problems and ways of their solution]. Ekonomika ta upravlinnia APK, 8, pp. 74-78 [In Ukrainian].

23. Mahler, P. (1994). Efficiency losses as a result of insufficient structural adjustments due to the EU sugar regime: the case of Germany. European Review of Agricultural Economics, Vol. 21, No. 2, pp. 199-218 [In English].

24. Stasinevych, S.A. (2013). Mekhanizm derzhavnoho tsinovoho rehuliuvannia $v$ tsukroburiakovomu kompleksi Ukrainy [Mechanism of state price regulation in the sugar-beet complex of Ukraine]. Biznesinform, 5, pp. 172-177 [In Ukrainian].

25. Skrypnyk, A.V., Zhemoida, O.V., \& Bukin, E.K. (2017). Analiz efektyvnosti vyrobnytstva pshenytsi za metodom Data Envelopment Analysis (DEA) [Efficiency analysis of wheat production using the Data Envelopment Analysis (DEA) method]. Ekonomika APK, 1, pp. 15-24 [In Ukrainian].

26. Skrypnyk, A.V., Tkachuk, V.A., Andruschenko, V.M., \& Bukin, E. (2018). Sustainable development facets: farmland market demand estimation. Journal of Security and Sustainability Issues, Vol. 7, No. 3. Retrieved from: https://jssidoi.org/jssi/papers/papers/journal/27 [In English].

\section{Букін Е.К. Аналіз часткової рівноваги політики виробництва цукру в Україні}

Мета статmi - проаналізувати вплив аграрної політики в цукровій галузі України на ринкову рівновагу попиту і пропозиції, дослідити механізм впровадження виробничої квоти (А) на рафінований цукор та його ефективність щодо ринкової рівноваги.

Методика дослідження. У дослідженні використано методи аналізу часткової рівноваги попиту і пропозиції на ринку цукру та елементи аналізу добробуту. За допомогою цього можна зрозуміти, яким чином досягається рівноважна ціна на внутрішньому ринку та як механізми впровадження аграрної політики впливають на неї.

Результати дослідження. Розкрито, яким чином виробнича квота (А) розподіляється між цукровиробниками на неконкурентних засадах, внаслідок чого штучно завищуються ціни на внутрішньому ринку, що негативно впливає на ринкову конкуренцію. Враховуючи, що ефективні та конкурентні виробники отримують відносно невеликі обсяги цукрової квоти, поточна політика негативно впливає на інвестиційну привабливість галузі, що не сприяє розвитку їі конкурентності. Як наслідок, обсяги цукрового виробництва залишаються на рівні нестабільного забезпечення внутрішнього попиту.

Елементи наукової новизни. Напрацьований матеріал $\epsilon$ внеском в інформаційний доробок щодо використання методів часткової рівноваги для аналізу виробничої квоти. Адже випадок впровадження неповноцінної або гнучкої виробничої квоти ще не розглядався у науковій літературі, а тут формалізуються механізми взаємодії виробників $і$ державного регулятора в умовах такої аграрної політики.

Практична значущість. Обґрунтовано альтернативні ідеї аграрної політики, серед яких: повноцінне впровадження виробничої квоти, виробнича квота, якою можна обмінюватися та повна лібералізація. Аналітично також показано, що усі перераховані альтернативи виявляють позитивний ефект на сукупний добробут, знижуючи ринкову ціну та збільшуючи обсяги виробництва. Табл.: 1. Рис.: 5. Бібліогр.: 26.

Ключові слова: аналіз часткової рівноваги; політика в цукровій галузі; Україна; виробнича квота; аналіз добробуту; імпорт цукру.

Букін Едуард Костянтинович - аспірант кафедри економічної кібернетики, Національний університет біоресурсів і природокористування України (м. Київ, вул. Героїв Оборони, 15)

E-mail: edwardbukin@gmail.com

ORCID iD https://orcid.org/0000-0002-1003-1260 
Цель статьи - проанализировать влияние аграрной политики в сахарной отрасли Украины на рыночное равновесие спроса и предложения, исследовать механизм внедрения производственной квоты (А) на рафинированный сахар и его эффективность относительно рыночного равновесия.

Методика исследования. В исследовании использованы методы анализа частичного равновесия спроса и предложения на рынке сахара и элементы анализа благосостояния. С помощью этого можно понять, каким образом достигается равновесная цена на внутреннем рынке и как механизмы внедрения аграрной политики влияют на нее.

Результаты исследования. Раскрыто, каким образом производственная квота (A) распределяется между сахаропроизводителями на неконкурентных принципах, вследствие чего искусственно завышаются цены на внутреннем рынке, что негативно влияет на рыночную конкуренцию. Учитывая, что эффективные и конкурентные производители получают относительно небольшие объемы сахарной квоты, текущая политика негативно влияет на инвестиционную привлекательность отрасли, что не способствует развитию её конкурентности. Как следствие, объемы сахарного производства остаются на уровне нестабильного обеспечения внутреннего спроса.

Элементы научной новизны. Наработанный материал является вкладом в информационную составляющую об использовании методов частичного равновесия для анализа производственной квоты. Ведь случай внедрения неполноценной или гибкой производственной квоты еще не рассматривался в научной литературе, а тут формализируются механизмы взаимодействия производителей и государственного регулятора в условиях такой аграрной политики.

Практическая значимость. Обоснованы альтернативные идеи аграрной политики, среди которых: полноценное внедрение производственной квоты, производственная квота, которой можно обмениваться и полная либерализация. Аналитически также показано, что все перечисленные альтернативы проявляют положительный эффект на совокупное благосостояние, снижая рыночную цену и увеличивая объемы производства. Табл.: 1. Илл.: 5 . Библиогр.: 26.

Ключевые слова: анализ частичного равновесия; политика в сахарной отрасли; Украчна; производственная квота; анализ благосостояния; импорт сахара.

Букин эдуард Константинович - аспирант кафедры экономической кибернетики, Национальный университет биоресурсов и природопользования Украины (2. Киев, ул. Героев Обороны, 15)

E-mail: edwardbukin@gmail.com

ORCID iD https://orcid.org/0000-0002-1003-1260

The article has been received 05.02.2019

Revision: 29.03.2019

Бібліографічний опис для цитування:

Bukin E. K. Partial-equilibrium analysis of the Ukrainian sugar policy. Економіка АПК. 2019. № 4. C. $97-106$.

УДК 332.33:332.72

JEL Classification: Q15

DOI: https://doi.org/10.32317/2221-1055.201904106

A.О. КОРОБСЬКА

\section{Проблеми становлення ринкового обігу земель сільськогосподарського призначення в Україні}

Мета статmi - проаналізувати проблеми становлення ринку земель на сучасному етапі та визначити основні передумови його формування та розвитку.

Методика дослідження. У процесі дослідження були використані такі наукові методи: абстрактно-логічний (для систематизації наявного теоретичного матеріалу); діалектичний метод пізнання й системного підходу (у вивченні наукових праць вітчизняних і зарубіжних учених із дослідження становлення та розвитку ринку сільськогосподарських земель, використання практичного досвіду з метою формування теоретико-методичних основ дослідження); порівняння (для оцінки одержаних показників). Використано статистичні дані, а також методичні підходи щодо аналізу проблем становлення ринку земель на сучасному етапі та визначення основних передумов його формування та розвитку.

Результати дослідження. У процесі дослідження особливу увагу приділено питанню становлення ринку сільськогосподарських земель, основним його завданням та функціям. Проаналізовано досвід регулювання ринкового обігу земель зарубіжних країн. Наголошується, що відсутність в Україні земельного ринку призводить до негативних 